\title{
Suspension Synthesis of Surfactant-Free Cuprous Oxide Quantum Dots
}

\author{
Dongzhi Lai, ${ }^{1,2}$ Tao Liu, ${ }^{1}$ Xinyun Gu, ${ }^{1}$ Ying Chen, ${ }^{1}$ Jin Niu, ${ }^{1}$ \\ Lingmin $Y i,{ }^{1,2}$ and Wenxing Chen ${ }^{1,2}$ \\ ${ }^{1}$ Key Laboratory of Advanced Textile Materials and Manufacturing Technology, Ministry of Education, \\ Zhejiang Sci-Tech University, Hangzhou 310018, China \\ ${ }^{2}$ National Engineering Lab of Textile Fiber Materials and Processing Technology, Zhejiang Sci-Tech University, Hangzhou 310018, China
}

Correspondence should be addressed to Dongzhi Lai; laidzh@zstu.edu.cn and Wenxing Chen; wxchen@zstu.edu.cn

Received 20 October 2014; Revised 17 January 2015; Accepted 21 January 2015

Academic Editor: Shou-Yi Kuo

Copyright (C) 2015 Dongzhi Lai et al. This is an open access article distributed under the Creative Commons Attribution License, which permits unrestricted use, distribution, and reproduction in any medium, provided the original work is properly cited.

Suspension methods were used to synthesize surfactant-free $\mathrm{Cu}_{2} \mathrm{O}$ quantum dots $\left(\mathrm{Cu}_{2} \mathrm{O}-\mathrm{QDs}\right)$ in high precursor concentrations using sodium hypophosphite as a reducing agent. Transmission electron microscopy (TEM) observations indicated that a large amount of $\mathrm{Cu}_{2} \mathrm{O}$-QDs were synthesized with diameters ranging from 7 to $10 \mathrm{~nm}$. We propose a mechanism where DMSO acts as a surface passivation agent, explaining the possible formation of $\mathrm{Cu}_{2} \mathrm{O}-\mathrm{QD}$. Noticeably, the $\mathrm{Cu}_{2} \mathrm{O}-\mathrm{QD}$ s exhibited high and stable catalytic activity for the reduction of rhodamine B.

\section{Introduction}

Cuprous oxide $\left(\mathrm{Cu}_{2} \mathrm{O}\right)$ is an important transition metal oxide with potential applications in a range of technological fields. Being a p-type oxide semiconductor with a direct band gap of $2.17 \mathrm{eV}, \mathrm{Cu}_{2} \mathrm{O}$ has been found in wide ranging applications including photon-activated water splitting [1], solar cells [2], gas sensing [3], low-temperature CO oxidation [4], negativeelectrode materials [5], solar energy conversion [6], and photodegradation of organic pollutants [7].

The synthesis of $\mathrm{Cu}_{2} \mathrm{O}$ has been previously reported by several groups $[1,2,4,8-10]$. Normally, a template (soft or hard) or capping agent is used to control the growth direction and dimensions of $\mathrm{Cu}_{2} \mathrm{O}$ in the solution-based route [1113]; however, the template or capping agents may have an undesirable role in the final applications. It is therefore highly beneficial to develop an alternative method to produce $\mathrm{Cu}_{2} \mathrm{O}$ which excludes templates or capping agents. Pan and colleagues reported that both cubic and octahedral $\mathrm{Cu}_{2} \mathrm{O}$ nano- and microcrystals can be selectively synthesized by a simple wet chemical and capping-agent-free reduction route at room temperature [14]. Xu et al. reported a facile room temperature surfactant-free solution chemical route to fabricate $\mathrm{Cu}_{2} \mathrm{O}$ nanocrystals, through reducing newly prepared $\mathrm{Cu}(\mathrm{OH})_{2}$ using hydrazine hydrate or sodium ascorbate [15]. In both methods, the $\mathrm{Cu}_{2} \mathrm{O}$ nanoparticle sizes are between 200 and $500 \mathrm{~nm}$ showing the larger particles size weakened the nanoparticle size effect. On the other hand, the precursor concentrations in literature [15] are low, at only $0.0032 \mathrm{~mol} / \mathrm{L}$ which reduces the productivity of the particles and whilst increasing production costs.

Singhal et al. [16] reported a surfactant-free solvothermal approach for the preparation of $\mathrm{Cu}_{2} \mathrm{O}$ nanocrystals involving the reaction of copper (II) acetylacetonate in acetone with a reaction temperature that reaches up to $140^{\circ} \mathrm{C}$, resulting in higher production costs. It is therefore desirable to design a low cost, room-temperature, convenient, high precursor concentration, and simple approach to produce surfactantfree $\mathrm{Cu}_{2} \mathrm{O}-\mathrm{QDs}$.

In this report, we develop a surfactant (or polymer) free room temperature suspension approach for the synthesis of $\mathrm{Cu}_{2} \mathrm{O}-\mathrm{QD}$ s with high precursor concentrations. It is shown 
that $\mathrm{Cu}_{2} \mathrm{O}$-QDs can be successfully fabricated through reducing copper sulfate pentahydrate using sodium hypophosphite in the dimethyl sulfoxide. Furthermore, the precursor quantity has little effect on the particle size and morphology of the $\mathrm{Cu}_{2} \mathrm{O}$-QDs, which can be applicable to large-scale production of $\mathrm{Cu}_{2} \mathrm{O}$-QDs. Rhodamine $\mathrm{B}(\mathrm{RhB})$ is one of the most commonly used xanthenes dyes in the textile industry due to its good stability. In this study, degradation of RhB by $\mathrm{Cu}_{2} \mathrm{O}$-QDs is applied to test the catalytic activity of $\mathrm{Cu}_{2} \mathrm{O}$ QDs.

\section{Experiments}

2.1. Materials. All chemicals used were of analytical grade and commercially obtained without further purification. Copper sulfate pentahydrate $\left(\mathrm{CuSO}_{4} \cdot 5 \mathrm{H}_{2} \mathrm{O}\right.$, Hangzhou Gaojing Fine Chemical Co. Ltd.) acted as the precursor for the formation of $\mathrm{Cu}_{2} \mathrm{O}$-QDs and sodium hypophosphite $\left(\mathrm{NaH}_{2} \mathrm{PO}_{2}\right.$, Taicang Meida Reagent Co., Ltd.) acted as a reductant. Dimethyl sulfoxide (DMSO, Tianjin Yongda Chemical Reagent Co., Ltd.) was used as the solvent.

\subsection{Synthesis}

2.2.1. Suspension Phase Synthesis. 4, 8, or $12 \mathrm{~g}$ of copper sulfate pentahydrate and $20 \mathrm{~g}$ of sodium hypophosphite were added to $1 \mathrm{~L}$ of DMSO. The mixture was vigorously stirred for 3 hours at $25^{\circ} \mathrm{C}$. The yellow/green coloured mixture turned drab gradually with the addition of $1.5 \mathrm{~mL}$ of $\mathrm{H}_{2} \mathrm{SO}_{4}$. The nanoparticles produced were then washed three times in deionized water followed by washing in ethanol, then centrifuged, and vacuum-dried at $40^{\circ} \mathrm{C}$ overnight.

DMSO is a good ligand for $\mathrm{Cu}(\mathrm{II})[17,18]$. In the reaction system, DMSO complexed with $\mathrm{Cu}(\mathrm{II})$ and to form hexakis (dimethylsulfoxide) copper(II) complex as in [19]

$$
\begin{aligned}
& \mathrm{CuSO}_{4} \cdot 5 \mathrm{H}_{2} \mathrm{O}+6 \mathrm{OS}\left(\mathrm{CH}_{3}\right)_{2} \\
& \quad \longrightarrow\left[\mathrm{Cu}\left(\mathrm{OS}\left(\mathrm{CH}_{3}\right)_{2}\right)_{6}\right] \mathrm{SO}_{4}+5 \mathrm{H}_{2} \mathrm{O}
\end{aligned}
$$

$\left[\mathrm{Cu}\left(\mathrm{OS}\left(\mathrm{CH}_{3}\right)_{2}\right)_{6}\right] \mathrm{SO}_{4}$ was suspended in DMSO solution. This was confirmed by the addition of the copper sulfate pentahydrate into DMSO solution which becomes grass green under vigorous stirring (Figure $1(\mathrm{a})$ ). However, when stirring was stopped, the $\left[\mathrm{Cu}\left(\mathrm{OS}\left(\mathrm{CH}_{3}\right)_{2}\right)_{6}\right] \mathrm{SO}_{4}$ solid particles settled to the bottom of the vessel after 24 hours and the DMSO solution became transparent (Figure 1(b)). Similarly, sodium hypophosphite was insoluble in DMSO; therefore the reaction occurred on the surface of the $\left[\mathrm{Cu}\left(\mathrm{OS}\left(\mathrm{CH}_{3}\right)_{2}\right)_{6}\right] \mathrm{SO}_{4}$ or the sodium hypophosphite.

2.3. Catalytic Oxidation Experiment. The catalytic oxidation of $\mathrm{RhB}\left(2.5 \times 10^{-5} \mathrm{~mol} / \mathrm{L}\right)$ was conducted using $\mathrm{Cu}_{2} \mathrm{O}(2.5 \mathrm{~g} / \mathrm{L})$ and $\mathrm{H}_{2} \mathrm{O}_{2}(2.5 \mathrm{mmol} / \mathrm{L})$ at $50^{\circ} \mathrm{C}$. At given time intervals, the decoloration efficiency of the RhB was determined using a UV-vis spectrometer.

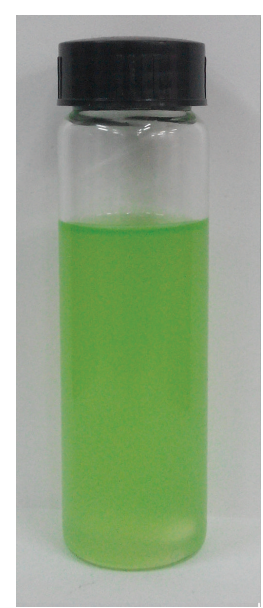

(a)

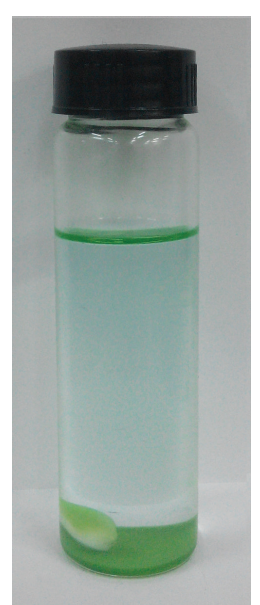

(b)
FIGURE 1: Copper sulfate pentahydrate in DMSO ((a) under stirring, (b) standing for $24 \mathrm{~h}$ ).

\subsection{Characterization}

$X$-Ray Diffraction (XRD). The crystal structure of $\mathrm{Cu}_{2} \mathrm{O}-\mathrm{QDs}$ was characterized using a Switzerland Thermo ARL XTRA Xray powder diffraction system using a $\mathrm{Cu} \mathrm{K}_{\alpha}$ radiation source at $35 \mathrm{kV}$ with a scan rate of $0.05^{\circ} / \mathrm{s}$ in the $2 \theta$ range of $10-80^{\circ}$.

Fourier Transform Infrared Spectroscopy (FTIR). The $\mathrm{Cu}_{2} \mathrm{O}-$ QDs powders were spread on $\mathrm{KBr}$ pellets individually and dried under an infrared lamp. The FTIR analysis was measured using a Nicolet 5700 FTIR spectrometer.

Transmission Electron Microscopy (TEM). The $\mathrm{Cu}_{2} \mathrm{O}-\mathrm{QDs}$ were suspended in ethanol and dropped on an ultra-thin carbon coated copper grid and dried under infrared lamp for 5 minutes. Images were acquired using a JSM-2100 transmission electron microscopy (TEM, JEOL, Japan) at an accelerating voltage of $200 \mathrm{kV}$.

Ultraviolet-Visible Spectroscopy (UV-Vis). The spectra were collected using a UV-3010 spectrophotometer across a wavelength range of $450-625 \mathrm{~nm}$.

Copper, carbon, sulfur, and oxygen atomic content and their bonds on the surface of nanoparticles were obtained from the XPS spectra. XPS spectra were acquired using a PHIl600 X hemispherical analyzer equipped with an Al Ka $(1486.6 \mathrm{eV}) \mathrm{X}$-ray source.

\section{Results and Discussion}

3.1. Phase Composition and Morphology of the Products. The phase composition of the products was determined via XRD (Figure 2). Bragg's reflections at $2 \theta$ value of $29.5^{\circ}, 36.4^{\circ}, 42.3^{\circ}$, $61.3^{\circ}$, and $73.5^{\circ}$ represent (110), (111), (200), (220), and (311) planes of $\mathrm{Cu}_{2} \mathrm{O}$ (PDF\#05-0667). No trace of $\mathrm{Cu}$ metal or $\mathrm{CuO}$ could be detected under the detection limits used for the $\mathrm{X}$-ray diffractometer. This indicated that the as-synthesized samples were of single phase $\mathrm{Cu}_{2} \mathrm{O}$. 


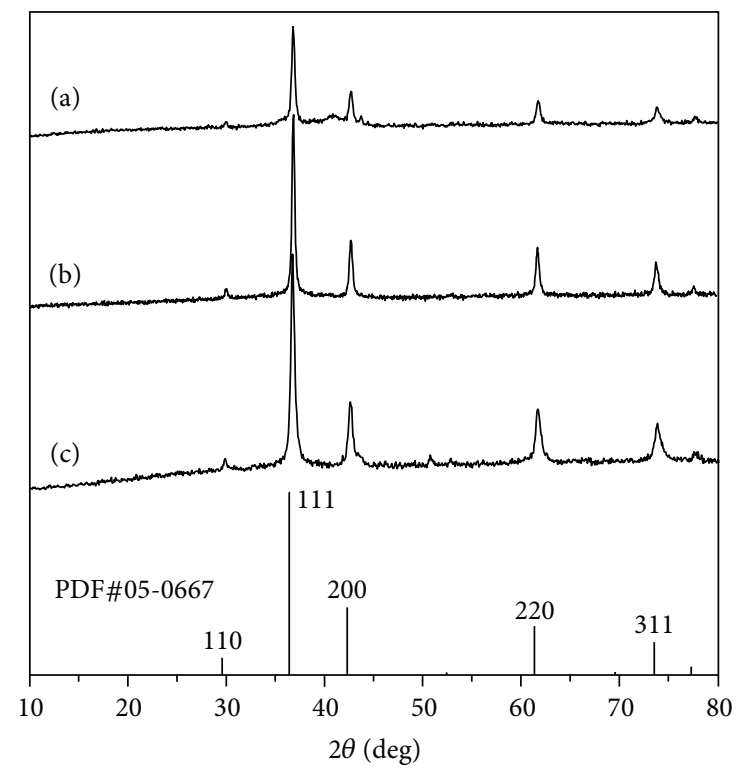

FIgURE 2: XRD pattern of $\mathrm{Cu}_{2} \mathrm{O}-\mathrm{QDs}$ freshly produced. $\left(\mathrm{CuSO}_{4} \cdot 5 \mathrm{H}_{2} \mathrm{O}\right.$ : (a) $4 \mathrm{~g} / \mathrm{L}$; (b) $8 \mathrm{~g} / \mathrm{L}$; (c) $\left.12 \mathrm{~g} / \mathrm{L}\right)$.

The morphology of the products was characterized by TEM (Figure 3). $\mathrm{Cu}_{2} \mathrm{O}$-QDs were shown to have an average diameter of $7 \mathrm{~nm}$ when the precursor quantity was $4 \mathrm{~g} / \mathrm{L}$ (seeing Figure 3(a)). No obvious change took place in the morphology and size of $\mathrm{Cu}_{2} \mathrm{O}-\mathrm{QDs}$ when the precursor quantity was increased to 8 or $12 \mathrm{~g} / \mathrm{L}$ (shown in Figure 3(b) or Figure 3(c)). These results revealed that the precursor quantity had little effect on morphology and size of the samples.

3.2. The FT-IR Spectra of $\mathrm{Cu}_{2} \mathrm{O}-\mathrm{QDs}$ and DMSO. The FT-IR spectra of $\mathrm{Cu}_{2} \mathrm{O}-\mathrm{QD}$ s and DMSO are presented in Figure 4. Several bands could be distinguished in the region of 4000$400 \mathrm{~cm}^{-1}$, a detailed assignment of which had been reported in a previous study. Briefly, the intense band of FT-IR spectra of DMSO at $1028 \mathrm{~cm}^{-1}$ was attributed to the $\mathrm{S}=\mathrm{O}$ bond vibration stretching modes and the peak located at $1308 \mathrm{~cm}^{-1}$ was due to the symmetric vibrations of $-\mathrm{CH}_{3}$ groups. The bands at 1399 and $1432 \mathrm{~cm}^{-1}$ were assigned to the asymmetric vibrations of $-\mathrm{CH}_{3}$ groups, and the peak split attributed to the vibration coupling effects. The bands at 2909 and $2992 \mathrm{~cm}^{-1}$ were characteristic of the $-\mathrm{CH}_{3}$ bond vibrations in the region of $4000-2500 \mathrm{~cm}^{-1}$.

Correspondingly, the intense band of the FTIR spectra of $\mathrm{Cu}_{2} \mathrm{O}-\mathrm{QDs}$ at $1096 \mathrm{~cm}^{-1}$ was attributed to the $\mathrm{S}=\mathrm{O}$ bond vibration stretching modes. The bands at 1374 and $1461 \mathrm{~cm}^{-1}$ were assigned to the symmetric and asymmetric vibrations of $-\mathrm{CH}_{3}$ groups, respectively. The bands at 2847 and $2917 \mathrm{~cm}^{-1}$ were characteristic of the $-\mathrm{CH}_{3}$ bond vibrations in the region of $4000-2500 \mathrm{~cm}^{-1}$. The peak at $628 \mathrm{~cm}^{-1}$ corresponded to the $\mathrm{Cu}-\mathrm{O}$ bond (due to optically active lattice vibration in the oxide) [20]. As these data show, DMSO was adsorbed on the surface of $\mathrm{Cu}_{2} \mathrm{O}-\mathrm{QD}$. The peak at $1067 \mathrm{~cm}^{-1}$ was assigned to the $\mathrm{S}=\mathrm{O}$ group which interacted with the $\mathrm{Cu}_{2} \mathrm{O}$ surface via the oxygen atom of DMSO.

The different peak positions of $\mathrm{S}=\mathrm{O}$ and methyl in the FT-IR spectra of $\mathrm{Cu}_{2} \mathrm{O}$-QDs and DMSO are mainly due to the following reasons: (1) the FT-IR spectra of $\mathrm{Cu}_{2} \mathrm{O}$ QDs were tested under solid conditions compared to the dimethyl sulfoxide under liquid conditions which resulted in the FTIR peak positions of $\mathrm{S}=\mathrm{O}$ and methyl of $\mathrm{Cu}_{2} \mathrm{O}-\mathrm{QD}$ being shifted to a high wave number; (2) the force constant of the $\mathrm{S}=\mathrm{O}$ increases with the characteristic frequency of the $\mathrm{S}=\mathrm{O}$ shifting to the high wavenumber displacement due to the inductive effect of the $\mathrm{Cu}^{+}$[21].

3.3. The XPS Spectra of $\mathrm{Cu}_{2} \mathrm{O}-\mathrm{QDs}$. The surface properties of the nanoparticles were studied by XPS analysis. Figure 5 shows the complete XPS spectra from 0 to $1350 \mathrm{eV}$ for the sample. The XPS spectra from a wide scan showed that the surface of the $\mathrm{Cu}_{2} \mathrm{O}$-QDs consisted of copper, sulfur, carbon, and oxygen elements.

The $\mathrm{Cu} 2 \mathrm{p}_{3 / 2}$ core level was used to investigate the $\mathrm{Cu}_{2} \mathrm{O}$ QDs surface. Figure 6(a) showed the main and satellite peaks of $\mathrm{Cu} 2 \mathrm{p}_{1 / 2}$ and $\mathrm{Cu} 2 \mathrm{p}_{3 / 2}$ in the samples. Cupric oxide $(\mathrm{CuO})$ and cuprous oxide $\left(\mathrm{Cu}_{2} \mathrm{O}\right)$ are the two semiconducting phases of copper oxide. In Figure 6(a), the spectrum displayed a $\mathrm{Cu} 2 \mathrm{p}_{3 / 2}$ peak at $931.88 \mathrm{eV}$ with a shoulder at $934.48 \mathrm{eV}$, which corresponded to $\mathrm{Cu}$ and/or $\mathrm{Cu}_{2} \mathrm{O}$ and $\mathrm{CuO}$, respectively. A shake-up satellite peak at $943.48 \mathrm{eV}$ and some peaks above $950 \mathrm{eV}$ were detected arising from spinorbit coupling $[22,23]$. $\mathrm{Cu}$ and $\mathrm{Cu}_{2} \mathrm{O}$ cannot be resolved due to their binding energies being very close, differing by only $0.1 \mathrm{eV}$ [24]. It was not easy to distinguish the binding energy of $\mathrm{Cu} 2 \mathrm{p}$ between $\mathrm{Cu}$ and $\mathrm{Cu}_{2} \mathrm{O}$, but they could be distinguished from the position of their corresponding LMM-2 auger transition in the XPS spectra at $568 \mathrm{eV}$ and $570 \mathrm{eV}$ for $\mathrm{Cu}$ and $\mathrm{Cu}_{2} \mathrm{O}$, respectively [25]. In Figure 6(b), a peak is observed at close to $570 \mathrm{eV}$ in the XPS spectra of the sample. According to the above descriptions, the peak at $931.88 \mathrm{eV}$ relates to $\mathrm{Cu}_{2} \mathrm{O}$. The relative intensities of the shakeup satellites from these levels were indicative of the presence of $\mathrm{CuO}$ at the surface [26]. The fact that XRD did not show evidence of $\mathrm{CuO}$ phase whilst XPS indicated the surface presence of $\mathrm{Cu}^{2+}$ ions suggests that $\mathrm{CuO}$ was present only on the surface of the $\mathrm{Cu}_{2} \mathrm{O}$-QDs $\mathrm{d}$ forms a thin amorphous outer shell [27].

Figure 7 shows the $S 2 p$ (Figure 7(a)), C 1s (Figure 7(b)), and $\mathrm{O}$ 1s XPS spectra. Figure 7(a) shows the $S 2 p$ peak at $167.88 \mathrm{eV}$ which is attributed to $\mathrm{S}=\mathrm{O}$ bonds $[28,29]$. In Figure 7(b), the main peak at $284.28 \mathrm{eV}$ of C 1 s was attributed to $\mathrm{C}-\mathrm{H}$ bonds [24]. From the position of the peak at $530.88 \mathrm{eV}$ in the $\mathrm{O}$ 1s spectra in Figure 7(c), this assigned the $\mathrm{O}$ 1s spectral to the $\mathrm{Cu}-\mathrm{O}$ bonds [30]. XPS characterization indicated that the surface of the $\mathrm{Cu}_{2} \mathrm{O}$-QDs was mainly $\mathrm{Cu}_{2} \mathrm{O}$ phase with $\mathrm{CuO}$ and DMSO covering a thin layer.

3.4. The Catalytic Activity of $\mathrm{Cu}_{2} \mathrm{O}-\mathrm{QDs}$. $\mathrm{Cu}_{2} \mathrm{O}$ can catalyze $\mathrm{H}_{2} \mathrm{O}_{2}$ to generate hydroxyl radicals [31-33]. The catalytic activity of $\mathrm{Cu}_{2} \mathrm{O}-\mathrm{QDs}$ is evidenced by the oxidation experiments of the model compound RhB. Degradation of $\mathrm{RhB}$ was 


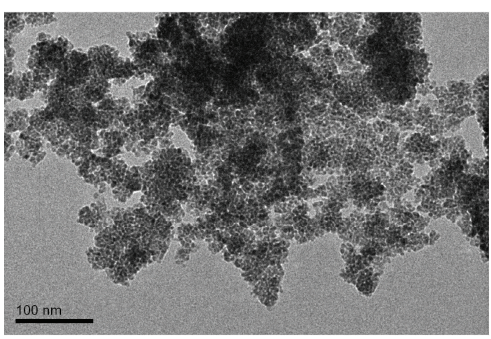

(a1)

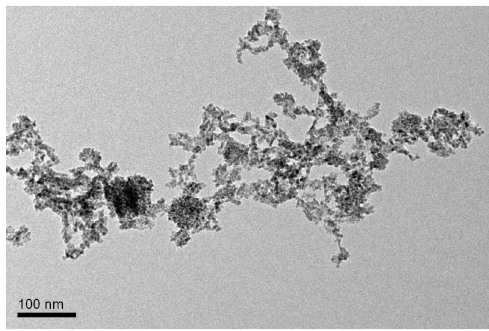

(b1)

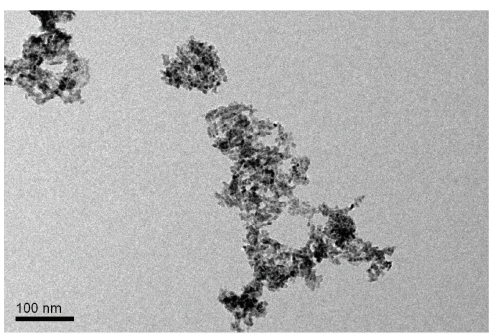

(c1)

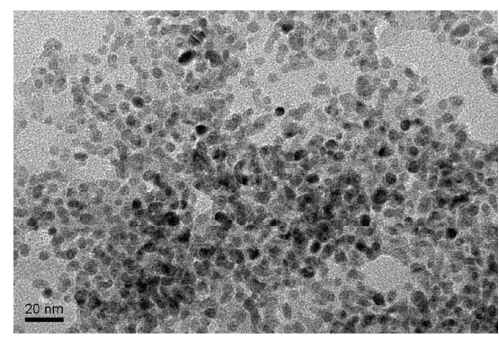

(a2)

(a)

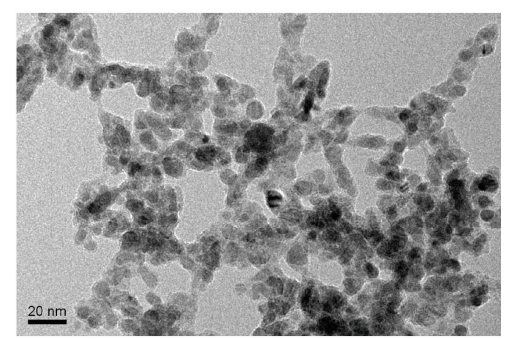

(b2)

(b)

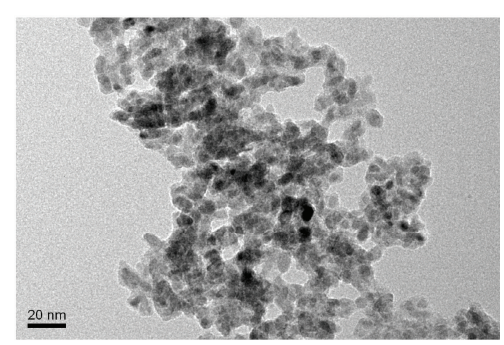

(c2)

(c)

Figure 3: TEM images of synthesized samples $\left(\mathrm{CuSO}_{4} \cdot 5 \mathrm{H}_{2} \mathrm{O}\right.$ : (a) $4 \mathrm{~g} / \mathrm{L}$; (b) $8 \mathrm{~g} / \mathrm{L}$; (c) $\left.12 \mathrm{~g} / \mathrm{L}\right)$.

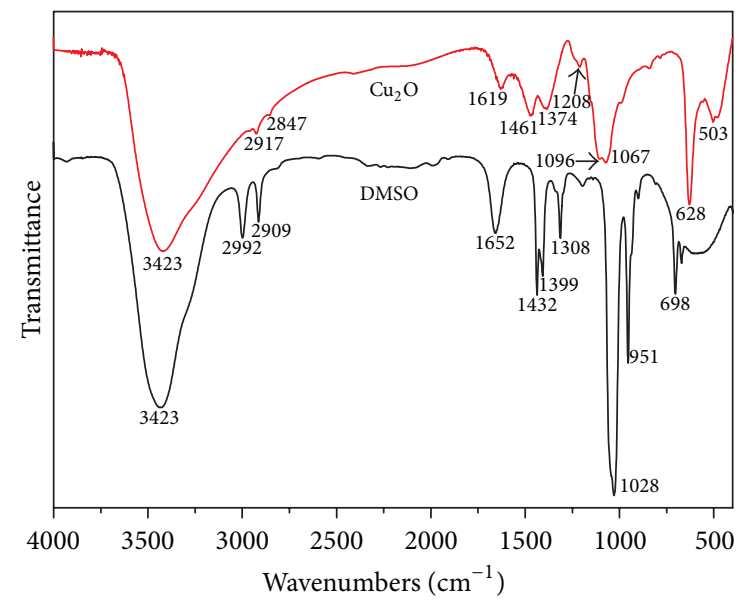

FIgURE 4: FTIR spectra of $\mathrm{Cu}_{2} \mathrm{O}-\mathrm{QD}$ and DMSO.

carried out at $50^{\circ} \mathrm{C}$ in the presence of hydrogen peroxide and $\mathrm{Cu}_{2} \mathrm{O}$-QDs. The absorption spectra of $\mathrm{RhB}$ solution during degradation is illustrated in Figure 8. The concentration of

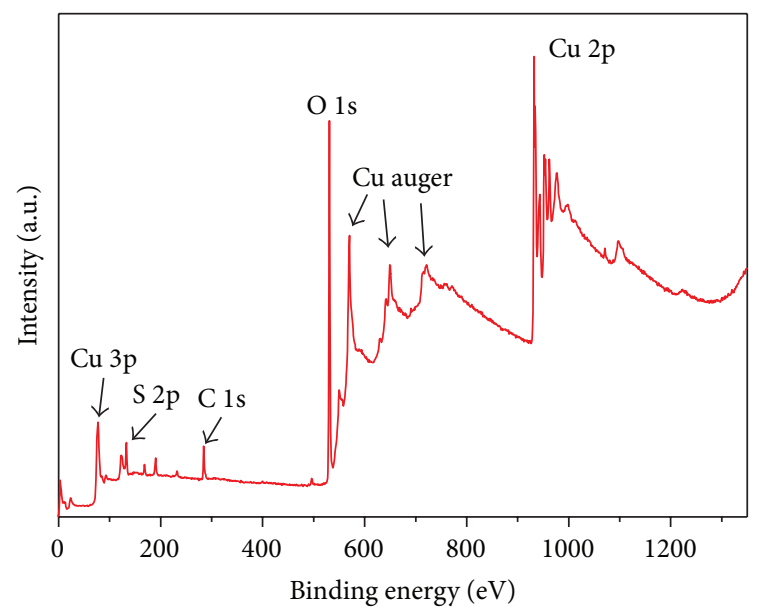

FIGURE 5: The complete XPS spectra of the sample.

RhB was calculated from the absorption in $\lambda_{\max }=555 \mathrm{~nm}$. As shown in Figure 8, the main absorption bands decreased with increasing reaction time which was consistent with the 


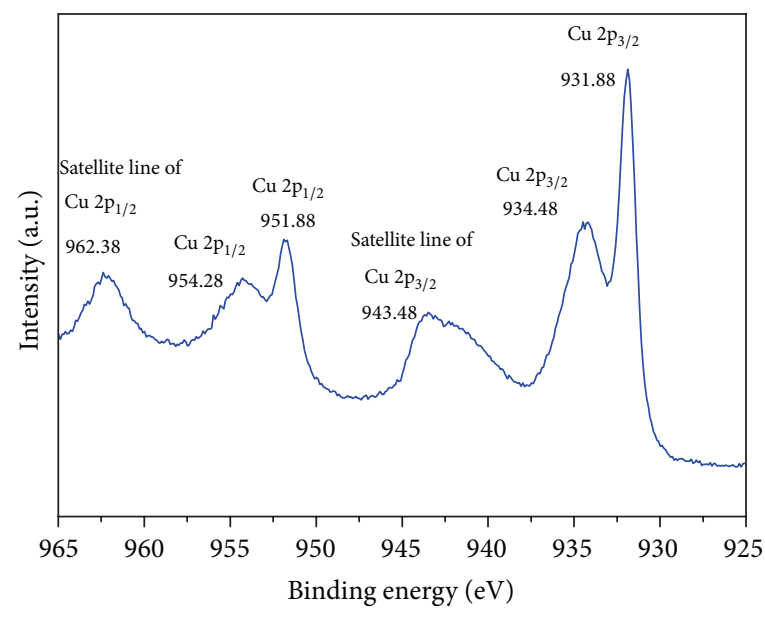

(a)

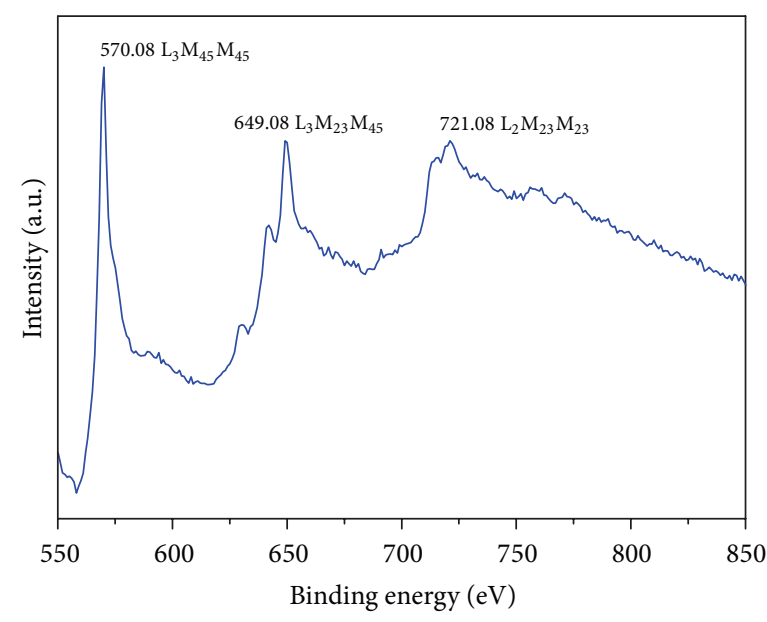

(b)

FIgURE 6: XPS (a) Cu 2p and (b) the $\mathrm{L}_{3} \mathrm{MM}$ Auger core-level spectra of the samples.

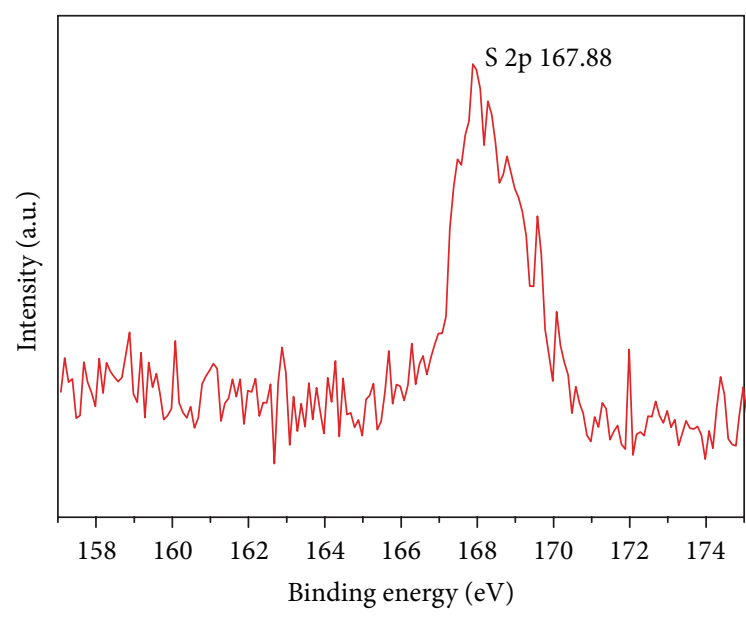

(a)

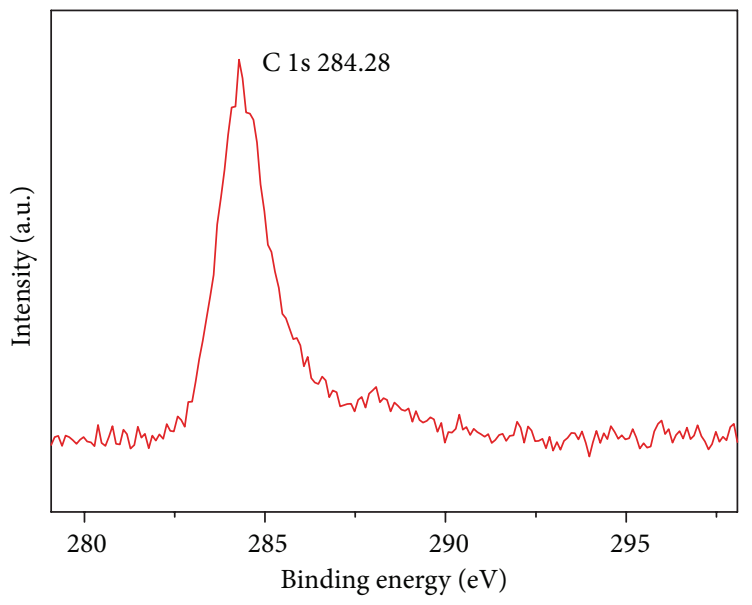

(b)

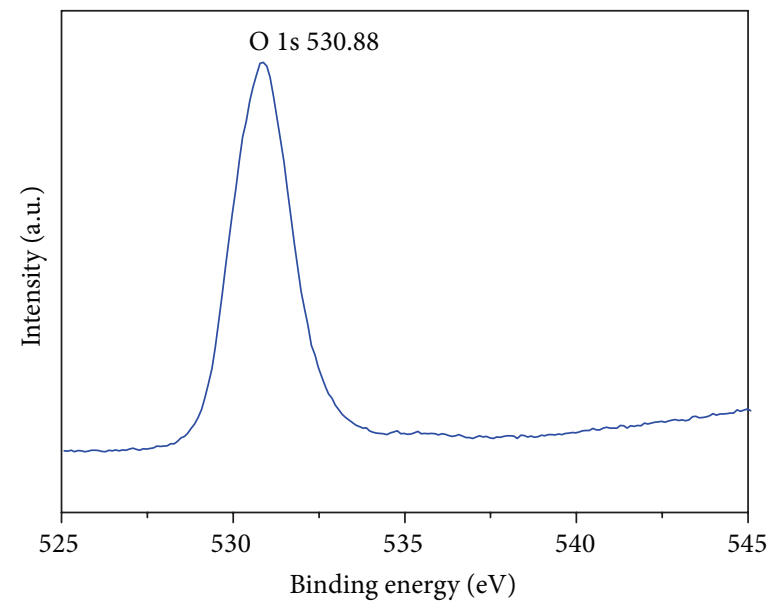

(c)

Figure 7: S 2p (a), C 1s (b), and O 1s (c) line of XPS spectra of the samples. 


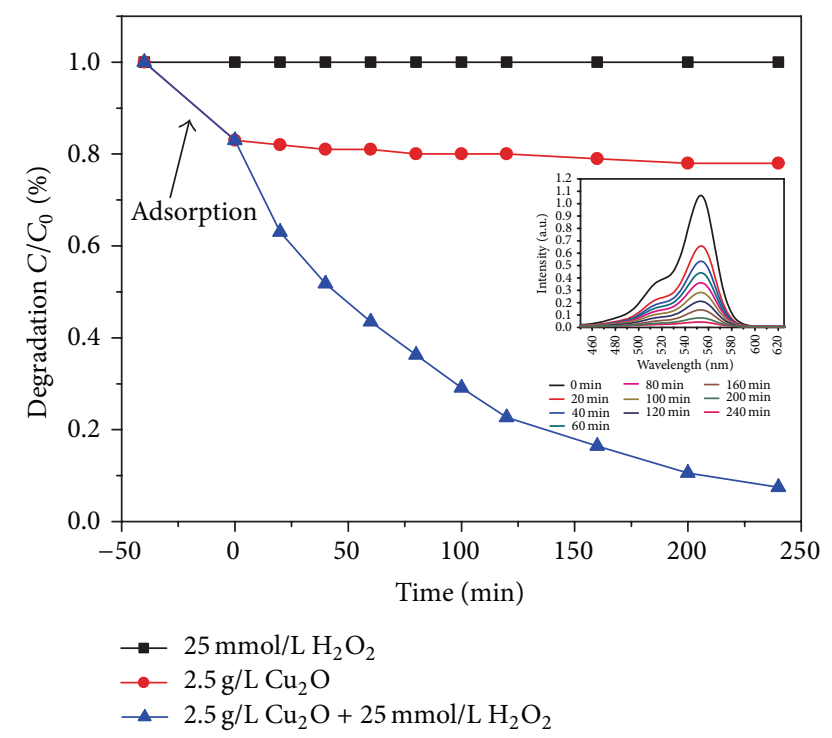

FIGURE 8: Concentration changes of RhB under different conditions. (inset: absorption spectra of RhB aqueous solution).

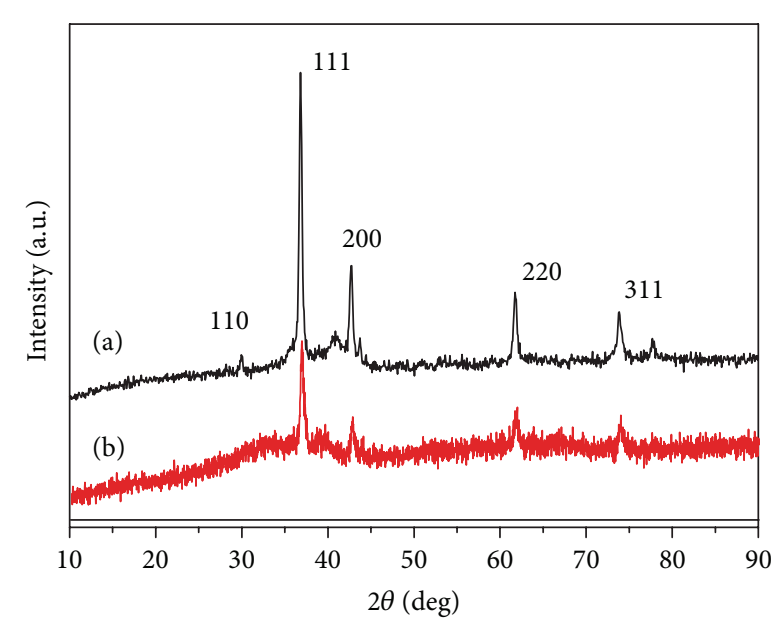

FIgURE 9: The phase composition of $\mathrm{Cu}_{2} \mathrm{O}$-QDs before (a) and after (b) ten cycles of use.

gradual colour change of the solution from red to colourless. The $\mathrm{RhB}$ was reduced to less than $4 \%$ after 240 minutes, indicating that $\mathrm{Cu}_{2} \mathrm{O}$-QDs possessed remarkable reductive ability.

The phase composition of $\mathrm{Cu}_{2} \mathrm{O}$-QDs after ten cycles of catalysis was further investigated by XRD (Figure 9). Results showed that the phase composition of the samples still matched to $\mathrm{Cu}_{2} \mathrm{O}$ (PDF\#05-0667). The height of each diffraction peak had decreased indicating that the $\mathrm{Cu}_{2} \mathrm{O}$ crystal structure was destroyed partly with the degree of crystallinity decreasing after repeated catalysis.

3.5. A Plausible Mechanism of the Reaction. If polymers or surfactants are absent in the reaction system, the nanoparticles would grow at the expense of the smaller particles due to Ostwald ripening. As the prepared $\mathrm{Cu}_{2} \mathrm{O}$-QDs were small in size and narrow in size distribution, this indicated that DMSO played a central role in controlling the morphology of $\mathrm{Cu}_{2} \mathrm{O}$ QDs.

It is known that the smaller the particle size, the larger the surface energy of the particle. The initial cuprous oxide crystal nuclei were small and had a high surface energy during the crystals growth stage. The DMSO adsorbed on the surface of the cuprous oxide particles via the oxygen atom of the $\mathrm{S}=\mathrm{O}$ group reduced the surface energy, which was verified by the FT-IR of $\mathrm{Cu}_{2} \mathrm{O}$-QDs. The greater steric resistance of DMSO made the cuprous oxide surfaces incompletely passivated, so the similar cuprous oxide particles grew up via Ostwald ripening. When the cuprous oxide particles reached a certain size, the surface energy became low as the surfaces were completely passivated by DMSO. This made the surface energy too small to drive the particles towards increased size causing the particles to remain small.

$\mathrm{NaH}_{2} \mathrm{PO}_{2}$ was used as the reduction in the overall reaction system. The fundamental reaction can be simplified as in [34]

$$
\begin{aligned}
& {\left[\mathrm{Cu}\left(\mathrm{OS}\left(\mathrm{CH}_{3}\right)_{2}\right)_{6}\right]^{2+}+\mathrm{H}_{2} \mathrm{PO}_{2}{ }^{-}} \\
& \longrightarrow \mathrm{Cu}_{2} \mathrm{O}+\mathrm{HPO}_{3}{ }^{-}+\mathrm{OS}\left(\mathrm{CH}_{3}\right)_{2}
\end{aligned}
$$

\section{Conclusions}

We report a novel, inexpensive, room temperature, high precursor concentration suspension method for the synthesis of surfactant-free $\mathrm{Cu}_{2} \mathrm{O}$-QDs. Experimental results showed that DMSO played a surface passivation role in the formation of $\mathrm{Cu}_{2} \mathrm{O}$-QDs. In this reaction system, varying the amount of precursors had little impact on the size of the product. The surface of the $\mathrm{Cu}_{2} \mathrm{O}$-QDs was mainly $\mathrm{Cu}_{2} \mathrm{O}$ phase with $\mathrm{CuO}$ and DMSO covering a thin layer. The $\mathrm{Cu}_{2} \mathrm{O}$-QDs samples had a high catalytic activity of $\mathrm{H}_{2} \mathrm{O}_{2}$ for the reduction of $\mathrm{RhB}$. The results in this paper provide evidence which support the suspension synthesis method for $\mathrm{Cu}_{2} \mathrm{O}$-QDs, broadening the scope of $\mathrm{Cu}_{2} \mathrm{O}-\mathrm{QD}$ s synthesis routes which may potentially be applied to the synthesis of other oxide materials.

\section{Conflict of Interests}

The authors declare that there is no conflict of interests regarding the publication of this paper.

\section{Acknowledgments}

This study was supported by the National Natural Science Foundation of China (nos. 51133006 and 21276243), the Open Fund for a Key Discipline of Zhejiang Province, and the Young Researchers Foundation of Key Laboratory of Advanced Textile Materials and Manufacturing Technology, Ministry of Education, Zhejiang Sci-Tech University (2012QN07). 


\section{References}

[1] P. E. De Jongh, D. Vanmaekelbergh, and J. J. Kelly, " $\mathrm{Cu}_{2} \mathrm{O}$ : a catalyst for the photochemical decomposition of water?" Chemical Communications, no. 12, pp. 1069-1070, 1999.

[2] K. Akimoto, S. Ishizuka, M. Yanagita, Y. Nawa, G. K. Paul, and T. Sakurai, "Thin film deposition of $\mathrm{Cu}_{2} \mathrm{O}$ and application for solar cells," Solar Energy, vol. 80, no. 6, pp. 715-722, 2006.

[3] H. Zhang, Q. Zhu, Y. Zhang, Y. Wang, L. Zhao, and B. Yu, "Onepot synthesis and hierarchical assembly of hollow $\mathrm{Cu}_{2} \mathrm{O}$ microspheres with nanocrystals-composed porous multishell and their gas-sensing properties," Advanced Functional Materials, vol. 17, no. 15, pp. 2766-2771, 2007.

[4] B. White, M. Yin, A. Hall et al., "Complete CO oxidation over $\mathrm{Cu}_{2} \mathrm{O}$ nanoparticles supported on silica gel," Nano Letters, vol. 6, no. 9, pp. 2095-2098, 2006.

[5] P. Poizot, S. Laruelle, S. Grugeon, L. Dupont, and J.-M. Tarascon, "Nano-sized transition-metal oxides as negative-electrode materials for lithium-ion batteries," Nature, vol. 407, no. 6803, pp. 496-499, 2000.

[6] A. O. Musa, T. Akomolafe, and M. J. Carter, "Production of cuprous oxide, a solar cell material, by thermal oxidation and a study of its physical and electrical properties," Solar Energy Materials and Solar Cells, vol. 51, no. 3-4, pp. 305-316, 1998.

[7] H. L. Xu, W. Z. Wang, and W. Zhu, "Shape evolution and size-controllable synthesis of $\mathrm{Cu}_{2} \mathrm{O}$ octahedra and their morphology-dependent photocatalytic properties," Journal of Physical Chemistry B, vol. 110, no. 28, pp. 13829-13834, 2006.

[8] M. J. Siegfried and K.-S. Choi, "Electrochemical crystallization of cuprous oxide with systematic shape evolution," Advanced Materials, vol. 16, no. 19, pp. 1743-1746, 2004.

[9] L. Gou and C. J. Murphy, "Solution-phase synthesis of $\mathrm{Cu}_{2} \mathrm{O}$ nanocubes," Nano Letters, vol. 3, no. 2, pp. 231-234, 2003.

[10] X. J. Zhang and Z. L. Cui, "One-pot growth of $\mathrm{Cu}_{2} \mathrm{O}$ concave octahedron microcrystal in alkaline solution," Materials Science and Engineering B: Solid-State Materials for Advanced Technology, vol. 162, no. 2, pp. 82-86, 2009.

[11] A. Radi, D. Pradhan, Y. Sohn, and K. T. Leung, "Nanoscale shape and size control of cubic, cuboctahedral, and octahedral $\mathrm{Cu}-$ $\mathrm{Cu}_{2} \mathrm{O}$ core-shell nanoparticles on $\mathrm{Si}(100)$ by one-step, templateless, capping-agent-free electrodeposition," ACS Nano, vol. 4, no. 3, pp. 1553-1560, 2010.

[12] L. Gou and C. J. Murphy, "Controlling the size of $\mathrm{Cu}_{2} \mathrm{O}$ nanocubes from 200 to $25 \mathrm{~nm}$," Journal of Materials Chemistry, vol. 14, no. 4, pp. 735-738, 2004.

[13] H. Zhang and Z. Cui, "Solution-phase synthesis of smaller cuprous oxide nanocubes," Materials Research Bulletin, vol. 43, no. 6, pp. 1583-1589, 2008.

[14] Z. Wang, H. Wang, L. Wang, and L. Pan, "Controlled synthesis of $\mathrm{Cu}_{2} \mathrm{O}$ cubic and octahedral nano-and microcrystals," Crystal Research and Technology, vol. 44, no. 6, pp. 624-628, 2009.

[15] Y. Xu, H. Wang, Y. Yu, L. Tian, W. W. Zhao, and B. Zhang, " $\mathrm{Cu}_{2} \mathrm{O}$ nanocrystals: surfactant-free room-temperature morphology-modulated synthesis and shape-dependent heterogeneous organic catalytic activities," Journal of Physical Chemistry C, vol. 115, no. 31, pp. 15288-15296, 2011.

[16] A. Singhal, M. R. Pai, R. Rao, K. T. Pillai, I. Lieberwirth, and A. K. Tyagi, "Copper(I) oxide nanocrystals-one step synthesis, characterization, formation mechanism, and photocatalytic properties," European Journal of Inorganic Chemistry, vol. 14, pp. 2640-2651, 2013.
[17] D. D. Swank, C. P. Landee, and R. D. Willett, "Crystal structure and magnetic susceptibility of copper (II) chloride tetramethylsulfoxide $\left[\mathrm{CuCl}_{2}\right.$ (TMSO)] and copper (II) chloride monodimethylsulfoxide [ $\left.\mathrm{CuCl}_{2}(\mathrm{DMSO})\right]$ : ferromagnetic spin-1/2 Heisenberg linear chains," Physical Review B, vol. 20, no. 5, pp. 2154-2162, 1979.

[18] K. K. Spektor, G. L. Starova, Y. M. Skripkin, and L. V. Stepakova, "Influence of acido ligands on the structure of copper dihalide solvates with dimethyl sulfoxide and N,N-dimethylformamide," Russian Journal of General Chemistry, vol. 81, no. 9, pp. 17721777, 2011.

[19] I. Persson, P. Persson, and M. J. Ullstrom, "Structure of JahnTeller distorted solvated copper(II) ions in solution, and in solids with apparently regular octahedral coordination geometry," Journal of the Chemical Society, Dalton Transactions, vol. 31, no. 7, pp. 1256-1265, 2002.

[20] Z. C. Orel, A. Anžlovar, G. Dražić, and M. Žigon, "Cuprous oxide nanowires prepared by an additive-free polyol process," Crystal Growth and Design, vol. 7, no. 2, pp. 453-458, 2007.

[21] H. Zhang, Modern Organic Spectroscopy Analysis, Chemical Industry Press, Beijing, China, 2005.

[22] J. Chastain and R. C. King Jr., Eds., Handbook of X-Ray Photoelectron Spectroscopy, Physical Electronics, Eden Prairie, Minn, USA, 1995.

[23] J. Ghijsen, L. H. Tjeng, J. van Elp et al., "Electronic structure of $\mathrm{Cu}_{2} \mathrm{O}$ and CuO," Physical Review B, vol. 38, no. 16, pp. 1132211330, 1988.

[24] T. Ghodselahi, M. A. Vesaghi, A. Shafiekhani, A. Baghizadeh, and M. Lameii, "XPS study of the $\mathrm{Cu} @ \mathrm{Cu}_{2} \mathrm{O}$ core-shell nanoparticles," Applied Surface Science, vol. 255, no. 5, pp. 2730-2734, 2008.

[25] J. Y. Park, Y. S. Jung, J. Cho, and W. K. Choi, "Chemical reaction of sputtered $\mathrm{Cu}$ film with PI modified by low energy reactive atomic beam," Applied Surface Science, vol. 252, no. 16, pp. 58775891, 2006.

[26] C. C. Chusuei, M. A. Brookshier, and D. W. Goodman, "Correlation of relative X-ray photoelectron spectroscopy shake-up intensity with $\mathrm{CuO}$ particle size," Langmuir, vol. 15, no. 8, pp. 2806-2808, 1999.

[27] M. Yin, C.-K. Wu, Y. B. Lou et al., "Copper oxide nanocrystals," Journal of the American Chemical Society, vol. 127, no. 26, pp. 9506-9511, 2005.

[28] L.-L. Ma, Z.-H. Qin, L. Zhang, X. Liu, and H. Chen, "Peak fitting methods and parameter settings in XPS analysis for organic sulfur in coal," Journal of Fuel Chemistry and Technology, vol. 42, no. 3, pp. 277-283, 2014.

[29] P. Chen, "Application of XPS in study forms of organic sulfur in macerals of Yanzhou coal," Journal of Fuel Chemistry and Technology, vol. 25, no. 3, pp. 283-241, 1997.

[30] P. E. Laibinis and G. M. Whitesides, "Self-assembled monolayers of n-alkanethiolates on copper are barrier films that protect the metal against oxidation by air," Journal of the American Chemical Society, vol. 114, no. 23, pp. 9022-9028, 1992.

[31] A. N. Pham, G. Xing, C. J. Miller, and T. D. Waite, "Fenton-like copper redox chemistry revisited: hydrogen peroxide and superoxide mediation of copper-catalyzed oxidant production," Journal of Catalysis, vol. 301, pp. 54-64, 2013.

[32] M. K. Eberhardt, G. Ramirez, and E. Ayala, "Does the reaction of $\mathrm{Cu}^{+}$with $\mathrm{H}_{2} \mathrm{O}_{2}$ give $\mathrm{OH}$ radicals? A study of aromatic hydroxylation," Journal of Organic Chemistry, vol. 54, no. 25, pp. 5922$5926,1989$. 
[33] M. R. Gunther, P. M. Hanna, R. P. Mason, and M. S. Cohen, "Hydroxyl radical formation from cuprous ion and hydrogen peroxide: a spin-trapping study," Archives of Biochemistry and Biophysics, vol. 316, no. 1, pp. 515-522, 1995.

[34] S. L. Xu, X. Y. Song, C. H. Fan et al., "Kinetically controlled synthesis of $\mathrm{Cu}_{2} \mathrm{O}$ microcrystals with various morphologies by adjusting $\mathrm{pH}$ value," Journal of Crystal Growth, vol. 305, no. 1, pp. $3-7,2007$. 

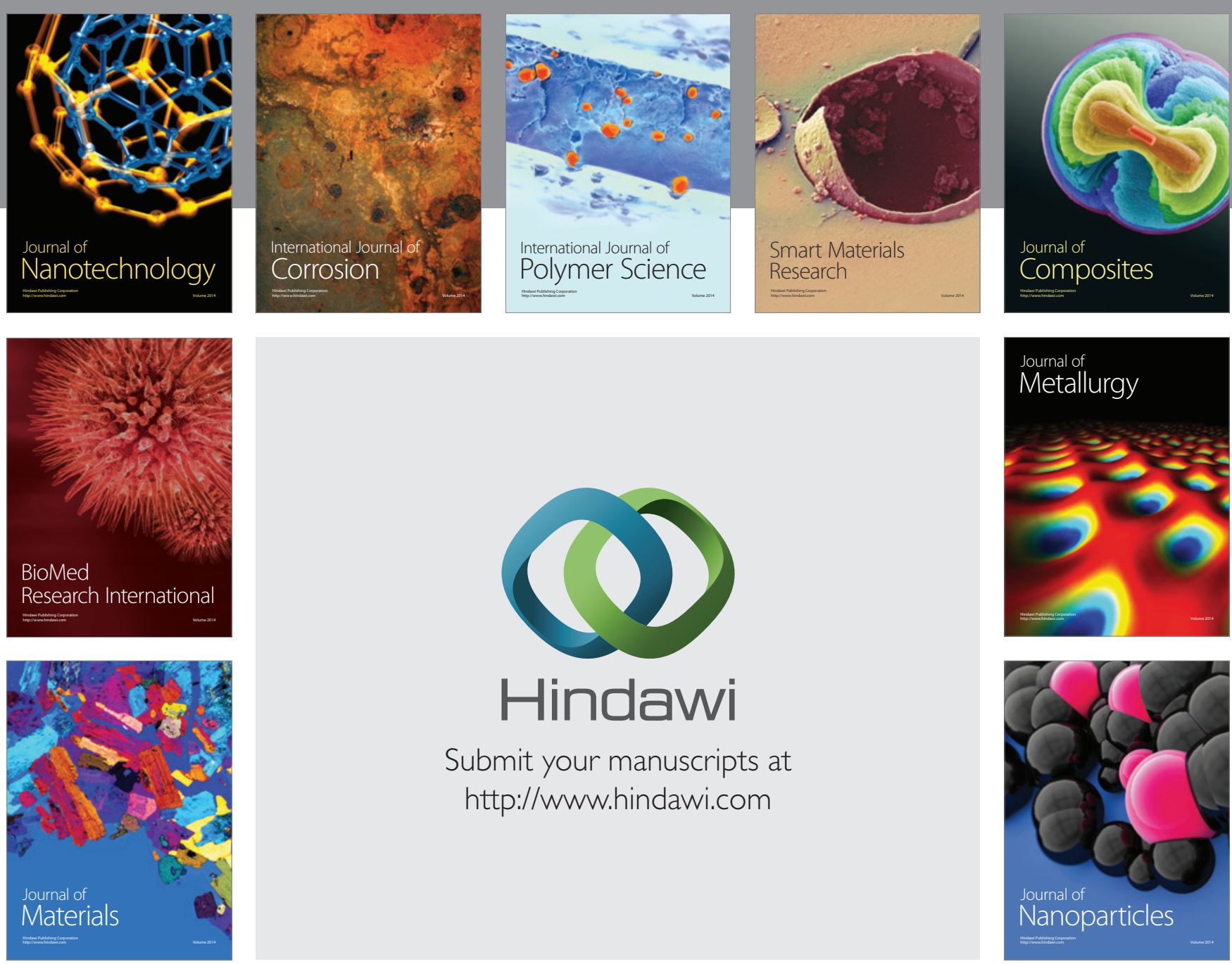

Submit your manuscripts at http://www.hindawi.com
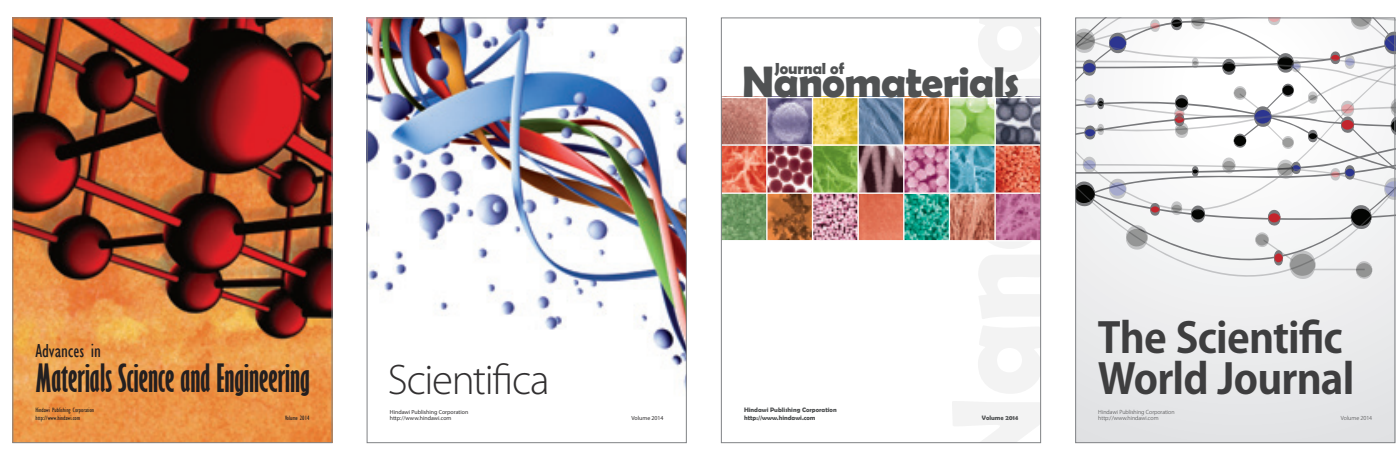

\section{The Scientific World Journal}
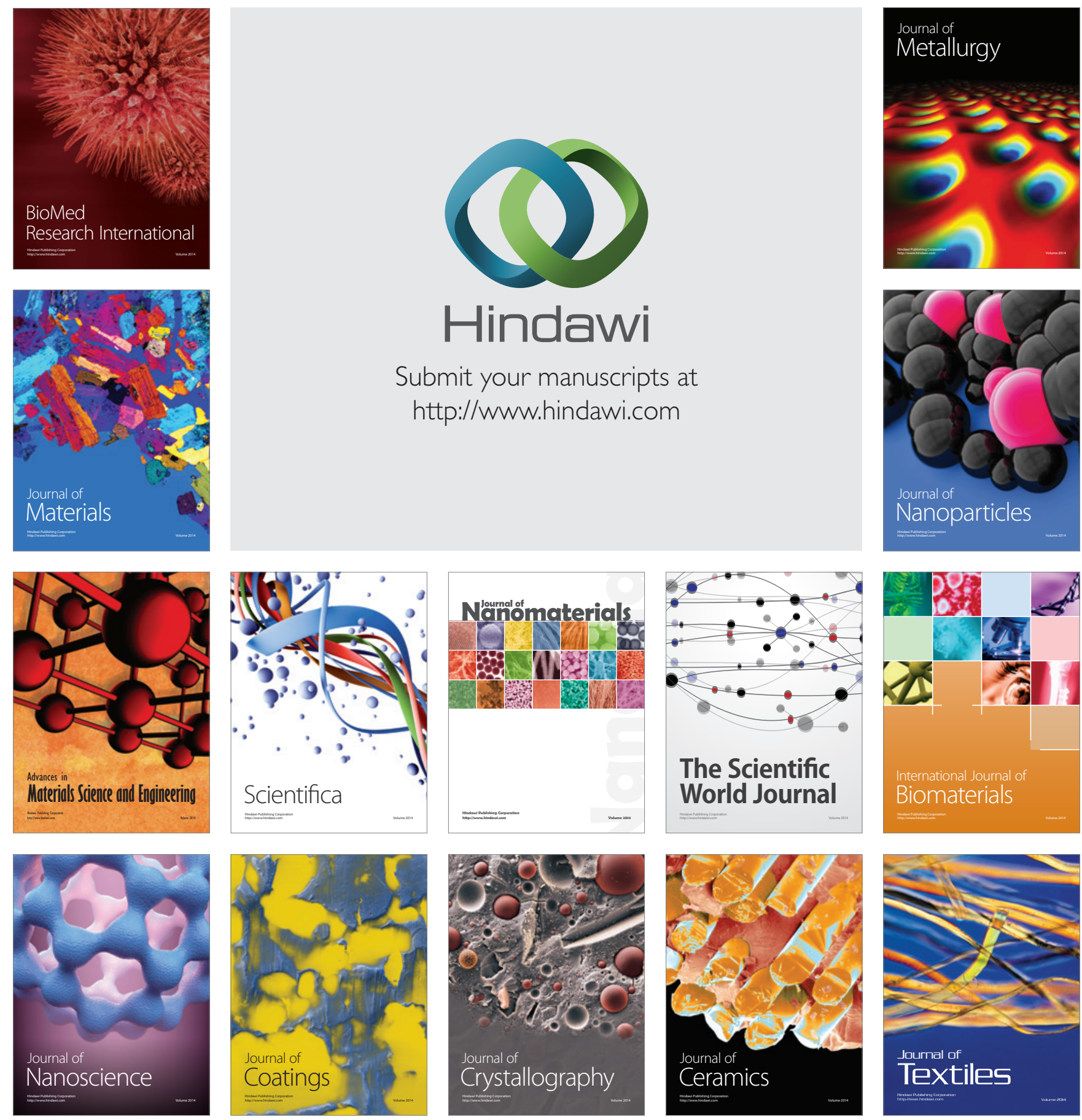